Received: 8 May 2017

Accepted: 2 August 2017

Published online: 06 September 2017

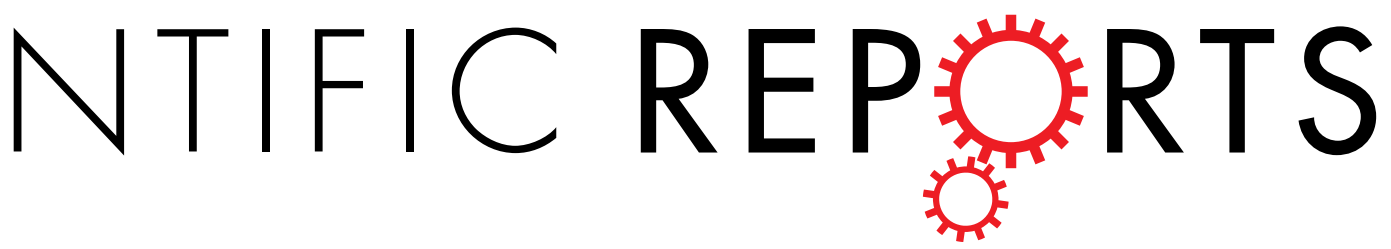

\title{
Enhancement of the productivity of the potent bacteriocin avicin $A$ and improvement of its stability using nanotechnology approaches
}

Hazem A. Fahim ${ }^{1}$, Waleed M. A. El Rouby ${ }^{2}$, Ahmed O. El-Gendy ${ }^{3}$, Ahmed S. Khairalla $\mathbb{D}^{3}$, Ibrahim A. Naguib ${ }^{4}$ \& Ahmed A. Farghali ${ }^{2}$

Herein, enhancements of the yield and antimicrobial activity duration of the bacteriocin avicin A were accomplished using fractional factorial design (FFD) and layered double hydroxide (LDH) nanoparticles. Firstly, potential factors affecting bacteriocin production were selected for preliminary study. By a $2^{5-1} \mathrm{FFD}$, high $\mathrm{pH}$ was shown to have a positive effect on avicin $\mathrm{A}$ yield, while temperature and duration of incubation, as well as peptone nitrogen sources all had negative effects. The highest bacteriocin production and activity $(2560 \mathrm{BU} / \mathrm{ml})$ were observed after $30 \mathrm{~h}$ of incubation at $30^{\circ} \mathrm{C}$, with $\mathrm{pH}$ adjustment at 7 , and in the presence of $2 \mathrm{~g}$ mannitol as carbon source and $2.2 \mathrm{~g}$ peptone as nitrogen source. Secondly, avicin A nanocomposites with different LDH precursors were tested. Only avicin A-ZnAI- $\mathrm{CO}_{3} \mathrm{LDH}$ demonstrated a potent antimicrobial activity against Lactobacillus sakei LMGT 2313 that lasted for at least 24 days, as compared to the values of 6 and 15 days observed with the free avicin A that has been stored at room temperature and at $4^{\circ} \mathrm{C}$, respectively. In conclusion, avicin $\mathrm{A}$ production and stability can be improved by manipulating the growth conditions and media composition, together with conjugation to LDHs.

Bacteriocins are a miscellaneous group of proteinaceous compounds, produced by diverse bacteria, which usually demonstrate antibacterial activity against species closely related to the bacteriocinogenic strain ${ }^{1}$. Generally, bacteriocins have been used as biopreservatives in the food industry and as antibacterial agents in the biomedical sector $^{2,3}$. These two applications are accomplished either by the direct use of bacteriocin in a relatively pure form, or through the incorporation of a bacteriocin-producer strain (as a probiotic) ${ }^{2}$.

Despite their promising applications, the commercial availability of bacteriocins is quite limited, due to challenges attributed to the proteinaceous nature of these compounds ${ }^{4}$. These challenges include: (i) the high costs for large scale production ${ }^{5}$; (ii) the low yield of the product, as a result of depending on complex media and ineffective purification methods $s^{6,7}$; and (iii) the loss of activity due to proteolytic degradation and/or unfavourable interactions with other food components ${ }^{5,8}$. Therefore, these challenges have to be met to enable a more efficient use of these compounds. Among the possible approaches to overcome the low yield and the high production costs of bacteriocins is to examine the variables affecting bacteriocin production. In this regard, different studies have examined the effects of various media composition and culture conditions on the yield of bacteriocins ${ }^{9,10}$. However, most of these studies have adopted conventional methods to maximize the yield, by changing one independent variable at a time while keeping other variables fixed. In addition of being extremely time consuming and expensive, especially for a large number of variables, these methods may also result in wrong conclusions $s^{11,12}$. Furthermore, neglecting the influence of interactions between the different factors is a major drawback of these methods. In order to save money and efforts, a fractional factorial experimental design was applied in this study

${ }^{1}$ Biotechnology and Life Sciences Department, Faculty of Postgraduate Studies for Advanced Sciences (PSAS), BeniSuef University, Beni-Suef, Egypt. ${ }^{2}$ Materials Science and Nanotechnology Department, Faculty of Postgraduate Studies for Advanced Sciences (PSAS), Beni-Suef University, Beni-Suef, Egypt. ${ }^{3}$ Microbiology and Immunology Department, Faculty of Pharmacy, Beni-Suef University, Beni-Suef, Egypt. ${ }^{4}$ Pharmaceutical Analytical Chemistry Department, Faculty of Pharmacy, Beni-Suef University, Beni-Suef, Egypt. Correspondence and requests for materials should be addressed to A.O.E.-G. (email: ahmed.elgendy@pharm.bsu.edu.eg) or A.S.K. (email: ahmedkhairalla@pharm.bsu.edu.eg) 


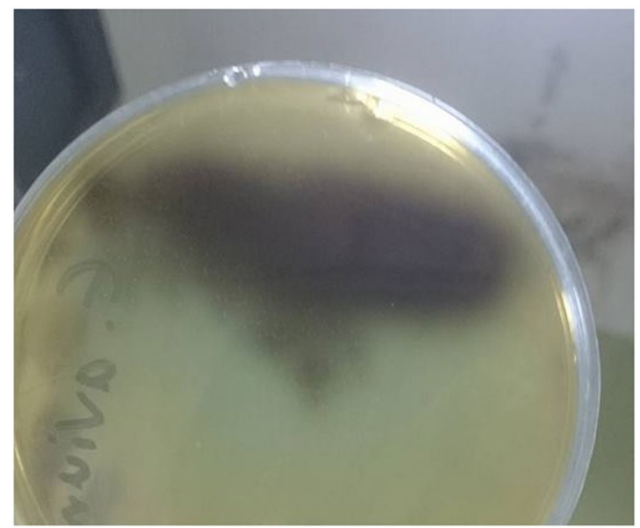

Figure 1. The growth of E. avium HF86 on bile esculin agar. The E. avium HF86 was tested after incubation for 24 and $48 \mathrm{~h}$ for esculin hydrolysis on bile esculin agar (Difco Laboratories; Detroit, USA). The formation of shiny black colonies confirms the identification of the test strain.

\begin{tabular}{|c|c|c|c|c|}
\hline $\begin{array}{l}\text { Target } \\
\text { gene }\end{array}$ & Primer sequence $\left(5^{\prime} \rightarrow 3^{\prime} \text { direction }\right)^{*}$ & $\begin{array}{l}\text { Amplicon } \\
\text { size (bp) }\end{array}$ & $\begin{array}{l}\text { Annealing } \\
\text { temperature } \\
\left({ }^{\circ} \mathrm{C}\right)\end{array}$ & Reference \\
\hline \multirow{2}{*}{$\begin{array}{l}16 \mathrm{~s}(\mathrm{SSU}) \\
\mathrm{rRNA}\end{array}$} & 1F: GAGTTTGATCCTGGCTCAG & \multirow{2}{*}{1106} & \multirow{2}{*}{56} & \multirow{2}{*}{36,37} \\
\hline & 12R: AGGGTTGCGCTCGTTG & & & \\
\hline \multirow{2}{*}{ Avicin A } & AV-F: ACGCGAAATGAAGAATGTTG & \multirow{2}{*}{156} & \multirow{2}{*}{55} & \multirow{2}{*}{38} \\
\hline & AV-R: GACTTCCAACCAGCAGCAC & & & \\
\hline
\end{tabular}

Table 1. PCR primers used in this study. *F: forward primer; R: reverse primer.

to assess the direct effect of each of the significant parameters, as well as to evaluate the possible interactions between these parameter, and thus have been crucial in defining the most influential conditions for maximum production of bacteriocin ${ }^{13}$.

The use of nano-carrier systems including liposomes, chitosan, nanofibers, and metal nanoparticles are relatively new approaches to protect bacteriocins from degradation ${ }^{4}$. However, the resulting nanoformulations have been found to vary in their ability to maintain their biological activity over long storage periods ${ }^{4}$. Therefore, it is of great interest to determine the appropriate nanotechnological approaches for each bacteriocin individually. Layered double hydroxides (LDHs) are a family of anionic clay materials that have the ability to intercalate neutral guest molecules and/or to exchange inorganic and organic ions between hydroxide layers ${ }^{14}$. Given their large surface area, biocompatibility, high anion exchange capacity, and chemical stability, LDHs have gained a considerable attention as a carrier for drugs and biological compounds ${ }^{15,16}$. Therefore, conjugation of bacteriocins with LDH could represent a potential solution to extend the shelf life and improve the commercial value of these antimicrobial peptides.

In a previous study, a bacteriocin-producing Enterococcus avium isolate was found to produce a new pediocin-like bacteriocin, named avicin $\mathrm{A}^{17}$. This bacteriocin has been shown to possess a potent antimicrobial activity against many species of Gram-positive bacteria, including the food-borne pathogen Listeria monocytogenes $^{17}$. Therefore, with an ultimate goal of enhancing the yield and stability of avicin A, the specific aims of the present study were to: (i) examine the effects of various $\mathrm{pH}$ values, incubation temperatures, incubation time, and medium components (including different types of carbon and nitrogen sources) on the yield of avicin A produced by E. avium HF86, and (ii) investigate the antimicrobial activity and stability of avicin A-LDH nanocomposites against Gram-positive and -negative bacteria.

\section{Confirmation of the Identity of the Bacteriocinogenic Isolate and Avicin A}

E. avium HF86 showed shiny black colonies on bile esculin agar, as a result of esculin hydrolysis (Fig. 1). When the antimicrobial activities of 9 antibiotics were tested against E. avium HF86, the isolate showed sensitivity to vancomycin and gentamicin only, while it was resistant to ampicillin/sulbactam, cefotaxime, ceftriaxone, cefoperazone, ceftazidime, erythromycin, and tetracycline (data not shown). In an effort to confirm the identity of the test strain, the DNA encoding the 16S rRNA was PCR-amplified using primers listed in Table 1, sequenced, and deposited in GenBank with accession number KY921715, which when blasted to NCBI RefSeq set, it showed 99\% similarity to the E. avium XA83 strain. In terms of bacteriocin production, the test isolate produced bacteriocin, as indicated by its ability to inhibit the growth of the sensitive indicator strain L. sakei LMGT 2313 (Fig. 2). The loss of bacteriocin activity after treatment with proteinase K enzyme (Fig. 2) confirmed the proteinaceous nature of the inhibitory substance. Also, the size of the reverse-transcribed PCR product (156bp, Fig. 3) added further strong support to the identity of our bacteriocin being avicin A. 


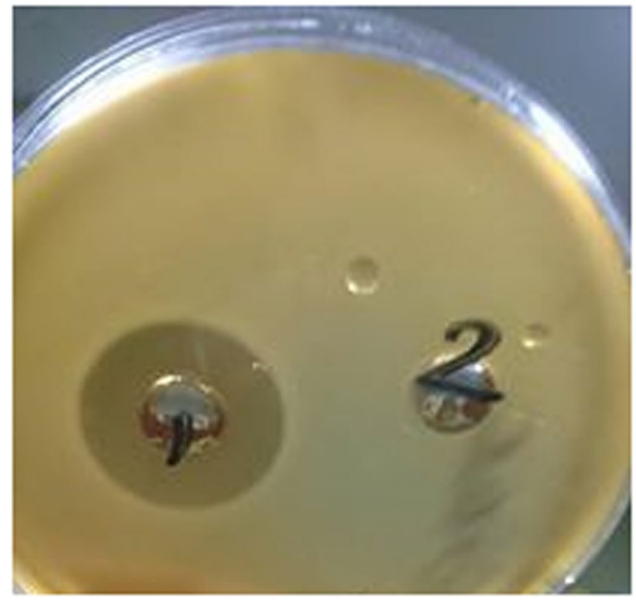

Figure 2. The antibacterial activity and the protein nature of avicin A. The antibacterial activity of avicin A was checked against L. sakei LMGT 2313, using the agar well diffusion method. While crude avicin A from the supernatant, which has been adjusted to $\mathrm{pH}$ 6.5, showed high antibacterial activity, as indicated by its ability to inhibit the growth of the sensitive indicator strain (well number 1), this activity was abolished completely when the supernatant was pre-treated with $1 \mathrm{mg} / \mathrm{ml}$ of proteinase $\mathrm{K}$ enzyme (Sigma) for $60 \mathrm{~min}$ at $37^{\circ} \mathrm{C}$ (well number 2 ), indicating the protein nature of avicin $\mathrm{A}$.

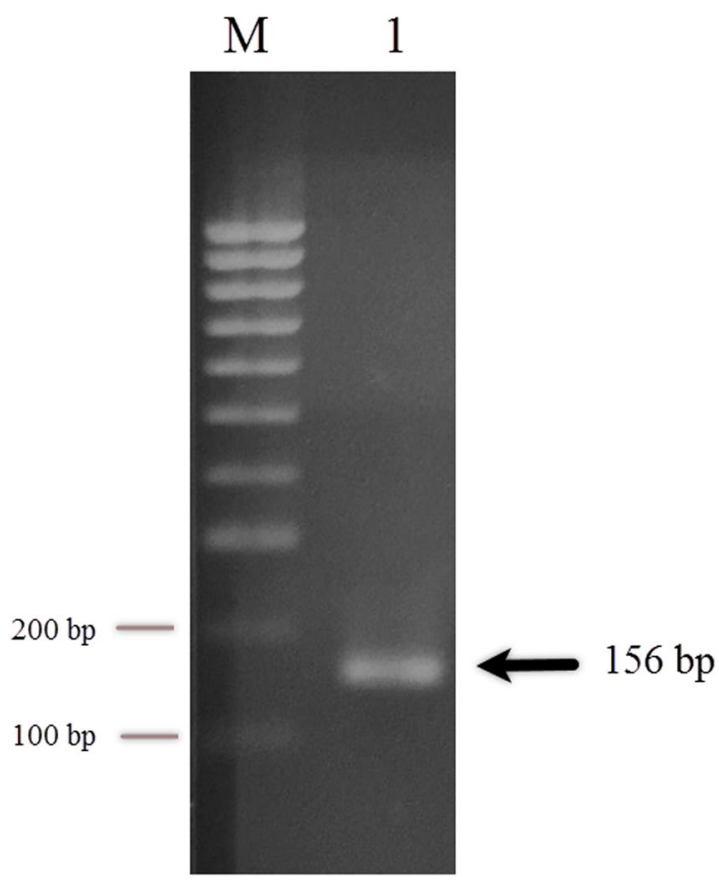

Figure 3. RT-PCR detection of avicin A mRNA. Total RNA $(1 \mu \mathrm{g})$ isolated from E. avium HF86 cells was reverse transcribed, and the resulting cDNA was amplified by a 35-cycle PCR with the primer pairs AV-F and AV-R (Table 1). The PCR product was visualized after agarose gel electrophoresis (2\%) with ethidium bromide. Lane 1 shows the reverse-transcribed PCR product of avicin A, and the arrow indicates the size of the product. The DNA molecular size marker is shown in the leftmost lane (lane M). Full-length gel is presented in Supplementary Figure S1.

The Effects of Medium Composition and Growth Conditions on Bacteriocin Production Based on the preliminary experiments: mannitol, lactose, peptone, protease peptone, initial $\mathrm{pH} 7$ and 8 , incubation periods of 18 and 30 hours, and incubation temperatures of $30^{\circ} \mathrm{C}$ and $20^{\circ} \mathrm{C}$ had a significant effect $\left(p^{<} 0.05\right)$ on avicin A production. With regard to carbon source, while all the tested sources resulted in the production of a bacteriocin with relatively high AMA against L. sakei LMGT 2313, the highest activities were obtained when cells were grown in mannitol or lactose. Furthermore, the highest AMA of the produced bacteriocin was attained in the presence of peptone or protease peptone as nitrogen sources (Table 2). In terms of growth conditions, the initial $\mathrm{pH}$ of the growth medium showed variable effect on the AMA, since the maximum activity was achieved 


\begin{tabular}{|l|l|l|}
\hline \multicolumn{2}{|l|}{$\begin{array}{l}\text { Factor } \\
\text { Concentration } \\
\text { of the factor } \\
(\mathrm{g} / 100 \mathrm{ml})\end{array}$} & $\begin{array}{l}\text { Zone of } \\
\text { inhibition } \\
\text { diameter }(\mathbf{m m})^{*}\end{array}$ \\
\hline Carbon source: & 2 & $13 \pm 0.57$ \\
\hline Glucose & 2 & $14.5 \pm 0.76$ \\
\hline Fructose & 2 & $18.83 \pm 0.44^{\mathrm{a}}$ \\
\hline Lactose & 2 & $14.67 \pm 0.88$ \\
\hline Succrose & 2 & $21 \pm 0.57^{\mathrm{b}}$ \\
\hline Mannitol & \multicolumn{2}{|l|}{} \\
\hline Nitrogen source: & 2.2 & $21 \pm 1^{\mathrm{c}}$ \\
\hline Peptone & 2.2 & $10 \pm 1.15$ \\
\hline Beef extract & 2.2 & $13.83 \pm 0.72$ \\
\hline Yeast extract & 2.2 & $10.33 \pm 1.20$ \\
\hline Ammonium sulphate & 2.2 & $16 \pm 0.57^{\mathrm{d}}$ \\
\hline Protease peptone & \multicolumn{2}{|l|}{}
\end{tabular}

Table 2. Effect of carbon and nitrogen sources on the production of avicin A, as indicated by the diameter of the zone of inhibition. *Data representing the average of triplicate values, are shown as mean \pm standard error of the mean. a Significantly different from glucose, $p<0.05$. bignificantly different from glucose, fructose, and sucrose, $p<0.05$. 'Significantly different from all nitrogen sources, $p<0.05$. ${ }^{\mathrm{d} S i g n i f i c a n t l y ~ d i f f e r e n t ~ f r o m ~ b e e f ~}$ extract and ammonium sulphate, $p<0.05$.

\begin{tabular}{|c|c|}
\hline Factor & Zone of inhibition diameter $(\mathrm{mm})^{*}$ \\
\hline \multicolumn{2}{|l|}{$p H:$} \\
\hline 4 & 0 \\
\hline 5 & 0 \\
\hline 6 & $13.67 \pm 0.33$ \\
\hline 7 & $19 \pm 1^{\mathrm{a}}$ \\
\hline 8 & $21.33 \pm 1.33^{\mathrm{b}}$ \\
\hline \multicolumn{2}{|c|}{ Incubation time (hours): } \\
\hline 6 & $12.33 \pm 0.66$ \\
\hline 12 & $13.83 \pm 0.44$ \\
\hline 18 & $18.67 \pm 0.33^{\mathrm{c}}$ \\
\hline 24 & $15.33 \pm 1.20$ \\
\hline 30 & $20.67 \pm 1.20^{\mathrm{d}}$ \\
\hline \multicolumn{2}{|c|}{ Incubation temperature $\left({ }^{\circ} \mathrm{C}\right)$ : } \\
\hline 20 & $16.67 \pm 1.20^{\mathrm{e}}$ \\
\hline 25 & $12 \pm 0.57$ \\
\hline 30 & $18.67 \pm 1.20^{\mathrm{f}}$ \\
\hline 37 & $13.83 \pm 0.16$ \\
\hline 40 & $8.33 \pm 0.88$ \\
\hline
\end{tabular}

Table 3. Effect of $\mathrm{pH}$, incubation time, and incubation temperature on the production of avicin $\mathrm{A}$, as indicated by the diameter of the zone of inhibition. *Data representing the average of triplicate values, are shown as mean \pm standard error of the mean. ${ }^{a}$ Significantly different from $\mathrm{pH}$ values $(4,5,6), p<0.05$. ${ }^{\text {b Significantly }}$ different from $\mathrm{pH}$ values $(4,5,6), p<0.05$. 'Significantly different from incubation time values $(6,12$ hours), $p<0.05$. ${ }^{\mathrm{d} S i g n i f i c a n t l y ~ d i f f e r e n t ~ f r o m ~ i n c u b a t i o n ~ t i m e ~ v a l u e s ~}(6,12,24$ hours $), p<0.05$. ${ }^{\text {SSignificantly different }}$

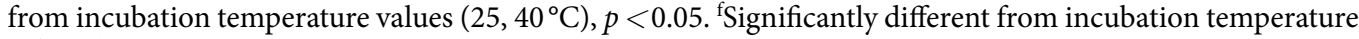
values $\left(25,37,40^{\circ} \mathrm{C}\right), p<0.05$.

at $\mathrm{pH} 7$ or 8 , while it was abolished at $\mathrm{pH} 4$ or 5 . Regarding incubation time, the inhibitory activity was detected after 6 hours of incubation, with a zone of inhibition of $12.33 \mathrm{~mm}$; then it increased gradually with time, showing 13.88 and $18.67 \mathrm{~mm}$ zones after incubation for 12 and 18 hours, respectively. In spite of the slight drop in the inhibition zone diameter to $15.33 \mathrm{~mm}$ after 24 hours of incubation, the inhibitory activity continued to increase with time, producing a $20.67 \mathrm{~mm}$ zone after 30 hours of incubation. When the AMA of avicin A was studied at different incubation temperatures, the inhibitory activity was the highest at $30^{\circ} \mathrm{C}$ and $20^{\circ} \mathrm{C}$ (corresponding to 18.67- and 16.67- mm zone diameters, respectivley) (Table 3). 


\begin{tabular}{|l|l|l|l|l|l|l|}
\hline \multirow{2}{*}{$\begin{array}{l}\text { Run } \\
\text { No }\end{array}$} & \begin{tabular}{l} 
Nutrient sources \\
\cline { 2 - 7 } \\
Source
\end{tabular} & Nitrogen source & $\mathbf{p H}$ & $\begin{array}{l}\text { Time } \\
(\text { hours })\end{array}$ & Temperature $\left({ }^{\circ} \mathbf{C}\right)$ & $\begin{array}{l}\text { Bacteriocin } \\
\text { activity }(\text { BU/ } \\
\text { ml }\end{array}$ \\
\hline 1 & Lactose & Protease peptone & 7 & 18 & 30 & 320 \\
\hline 2 & Lactose & Protease peptone & 7 & 30 & 20 & 10 \\
\hline 3 & Lactose & Protease peptone & 8 & 18 & 20 & 640 \\
\hline 4 & Lactose & Protease peptone & 8 & 30 & 30 & 80 \\
\hline 5 & Lactose & Peptone & 7 & 18 & 20 & 160 \\
\hline 6 & Lactose & Peptone & 7 & 30 & 30 & 20 \\
\hline 7 & Lactose & Peptone & 8 & 18 & 30 & 640 \\
\hline 8 & Lactose & Peptone & 8 & 30 & 20 & 10 \\
\hline 9 & Mannitol & Protease peptone & 7 & 18 & 20 & 320 \\
\hline 10 & Mannitol & Protease peptone & 7 & 30 & 30 & 40 \\
\hline 11 & Mannitol & Protease peptone & 8 & 18 & 30 & 320 \\
\hline 12 & Mannitol & Protease peptone & 8 & 30 & 20 & 10 \\
\hline 13 & Mannitol & Peptone & 7 & 18 & 30 & 80 \\
\hline 14 & Mannitol & Peptone & 7 & 30 & 20 & 40 \\
\hline 15 & Mannitol & Peptone & 8 & 18 & 20 & 80 \\
\hline 16 & Mannitol & Peptone & 8 & 30 & 30 & 20 \\
\hline
\end{tabular}

Table 4. Effect of the combination of multiple nutrient sources and incubation conditions on avicin A production. Five variables (i.e., mannitol and lactose as carbon sources; peptone and protease peptone as nitrogen sources; $\mathrm{pH}$; incubation time; and incubation temperature) having the highest influence on avicin A production were selected based on preliminary experiments. According to the 2-level 5 variables concept, a $2^{5-1}$ fractional design was considered, which lead to the 16 runs listed.

\section{Fractional Factorial Design Analysis}

The results of FFD experiments conducted to investigate the effects of media composition and growth conditions on avicin A production are shown in Table 4. Experiments were performed in triplicate, including different combinations of the tested factors and their possible interactions. The application of FFD produced the following regression equation, which is an empirical relationship between bacteriocin activity and test variables in coded units:

$$
\begin{aligned}
\text { Bacteriocin activity }(\mathrm{Y})= & 174.375+15.625 \mathrm{x}_{1}-145.625 \mathrm{x}_{2}+50.625 \mathrm{x}_{3}-43.125 \mathrm{x}_{4} \\
& -60.625 \mathrm{x}_{5}-4.375 \mathrm{x}_{1} \mathrm{x}_{2}+24.375 \mathrm{x}_{1} \mathrm{x}_{3}+43.125 \mathrm{x}_{1} \mathrm{x}_{4} 75 \mathrm{x}_{2} \mathrm{x}_{3} \\
& -14.375 \mathrm{x}_{1} \mathrm{x}_{5}-49.3+36.875 \mathrm{x}_{2} \mathrm{x}_{4}+59.375 \mathrm{x}_{2} \mathrm{x}_{5} \\
& +5.625 \mathrm{x}_{3} \mathrm{x}_{4}-56.875 \mathrm{x}_{3} \mathrm{x}_{5}+15.625 \mathrm{x}_{4} \mathrm{x}_{5}
\end{aligned}
$$

where $x_{1}$ is the carbon source; $x_{2}$ is the nitrogen source; $x_{3}$ is the initial $\mathrm{pH} ; x_{4}$ is the incubation time; and $x_{5}$ is the incubation temperature.

These given values (coefficients) represent the influence of each factor on bacteriocin production and also the impacts of factor-factor interactions. Additionally, the design matrix data were projected onto a two-dimensional (2D) scatter plot (i.e. score plot) to assure the symmetry of the design and the uniform distribution of test samples in space (Fig. 4). The most significant factors were found to be nitrogen source, incubation temperature, $\mathrm{pH}$, and incubation time; among which, only the $\mathrm{pH}$ showed a positive effect on bacteriocin production, while all the others had a negative effect (Fig. 5). To explain, raising the initial $\mathrm{pH}$ value to 8 enhanced the production of avicin $\mathrm{A}$, while the yield was decreased by increasing incubation temperature and duration of incubation, as well as using peptone as a nitrogen source. Additionally, a number of factor-factor interactions were observed, some of which exerted synergistic effects on bacteriocin production, including the interaction between nitrogen source and incubation temperature, as well as that between carbon source and incubation time (Fig. 5). These positive interactions suggest that bacteriocin production may be optimally achieved either following: (i) $30 \mathrm{~h}$ incubation at $30^{\circ} \mathrm{C}$ in a medium containing mannitol and peptone; or (ii) $18 \mathrm{~h}$ incubation at $20^{\circ} \mathrm{C}$ in a medium containing lactose and protease peptone. On the other hand, avicin A production was affected negatively by the interaction between $\mathrm{pH}$ and incubation temperature, as well as that between nitrogen source and $\mathrm{pH}$. These negative interactions suggest that bacteriocin yield is expected to decrease either following an incubation: (i) at $30^{\circ} \mathrm{C}$ in a medium with a $\mathrm{pH}$ of 8 ; (ii) in a peptone-containing medium adjusted to $\mathrm{pH} 8$; (iii) at $20^{\circ} \mathrm{C}$ in a medium with a $\mathrm{pH}$ of 7 ; or (iv) in a medium containing protease peptone that is adjusted to $\mathrm{pH} 7$. Given the results of interaction terms, avicin A production was investigated following $30 \mathrm{~h}$ incubation at $30^{\circ} \mathrm{C}$ in a medium containing $2 \mathrm{~g}$ mannitol and $2.2 \mathrm{~g}$ peptone (as carbon and nitrogen sources, respectively) and adjusted to initial $\mathrm{pH} 7$. In our hands, the yield of avicin A under the previously mentioned conditions $(2560 \mathrm{BU} / \mathrm{ml})$ was the maximum among all the conditions we examined. 


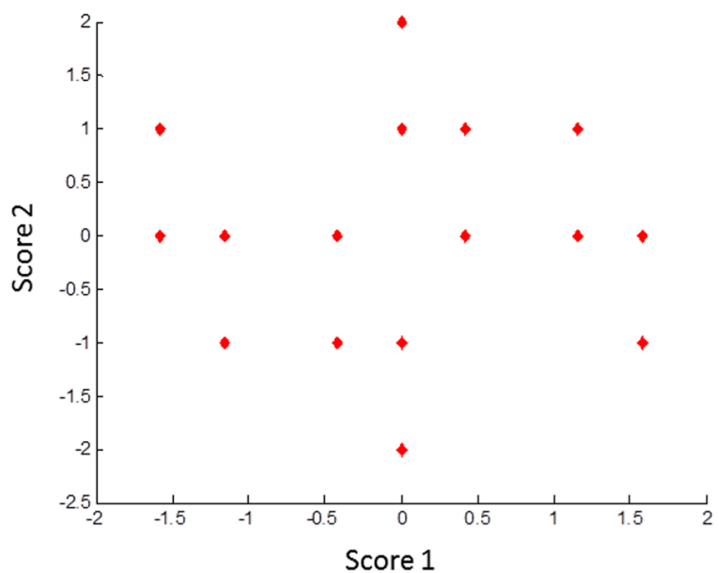

Figure 4. 2D scatter plot for the first two principal components after analysis of design matrix, showing the symmetric distribution of test samples in space.

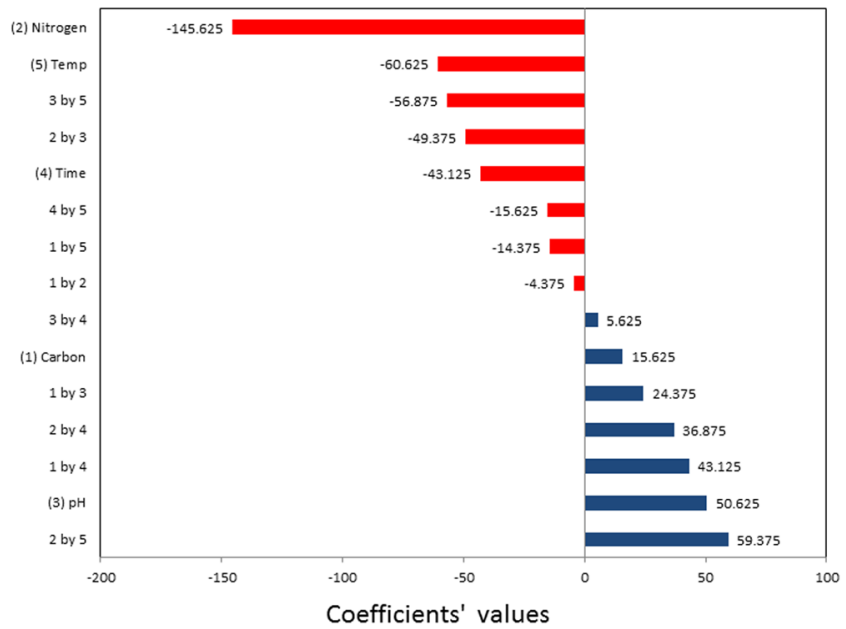

Figure 5. Pareto chart showing the relative magnitude of effects of the five factors identified for FFD and their first-order interactions on avicin A production. Tested factors were: carbon source (1), nitrogen source (2), $\mathrm{pH}$ (3), incubation time (4), and incubation temperature (5).

Physicochemical Characterizations of LDHs, Avicin A, and Avicin A-LDH Nanocomposites As shown in Fig. 6(b-d), the FT-IR spectra revealed an intense absorption band at around $3500 \mathrm{~cm}^{-1}$ for the three $\mathrm{LDHs}$, which can be attributed to the $\mathrm{OH}$ stretching of hydroxyl group and water molecules adsorbed on LDHs. The spectra also exhibited a strong absorption band around $1365 \mathrm{~cm}^{-1}$, mainly due to the presence of carbonate group. Regarding the nitrate group, the characteristic band caused by the stretching of the nitrate anions was detected at $1381 \mathrm{~cm}^{-1}$. In the FT-IR spectra of avicin A (Fig. 6a), there were four absorption bands (at 3256, 1636, 1087 , and $606 \mathrm{~cm}^{-1}$ ) due to unknown functional groups of this bacteriocin. After the formation of nanocomposites with LDHs, all the bands corresponding to avicin A functional groups were still clearly visible in avicin $\mathrm{A}-\mathrm{MgAl}-\mathrm{CO}_{3} \mathrm{LDH}$ and avicin A-MgAl-NO $\mathrm{N}_{3} \mathrm{LDH}$ nanocomposites (Fig. 6e and g). In the FT-IR spectra of avicin $\mathrm{A}-\mathrm{ZnAl}-\mathrm{CO}_{3} \mathrm{LDH}$ nanocomposite, the two peaks of avicin A at 3256 and $606 \mathrm{~cm}^{-1}$ were overlapped with peaks of LDH and shifted to 3446 and $611 \mathrm{~cm}^{-1}$ (Fig. 6f).

As shown in the XRD analysis presented in Fig. 7, all the LDHs examined (MgAl- $\mathrm{CO}_{3}, \mathrm{ZnAl}-\mathrm{CO}_{3}$, and $\mathrm{MgAl}-\mathrm{NO}_{3} \mathrm{LDHs}$ ) as well as the resulting avicin A-LDH nanocomposites exhibited sharp and symmetrical well-ordered reflection peaks, such as (003), (006), (009). For MgAl- $\mathrm{CO}_{3} \mathrm{LDH}$ (Fig. 7a), the peak corresponding to the reflection intensity $(100 \%)$ at $2 \theta=11.2905$ indicated that the basal spacing was $7.83724[\AA]$ and the crystallite size was $13.1 \mathrm{~nm}$. For $\mathrm{ZnAl}-\mathrm{CO}_{3} \mathrm{LDH}$ (Fig. 7c), the peak corresponding to the reflection intensity (100\%) at $2 \theta=11.7271$ indicated that the basal spacing was $7.54638[\AA]$ and the crystallite size was $48.5 \mathrm{~nm}$. Also, the XRD analysis of $\mathrm{ZnAl}-\mathrm{CO}_{3} \mathrm{LDH}$ showed an additional peak centred at $2 \theta=34.7$, and is thought to be most probably due to traces of zinc oxide phase (Fig. 7c). In the case of $\mathrm{MgAl}_{-} \mathrm{NO}_{3} \mathrm{LDH}$ (Fig. 7e), the peak corresponding to the reflection intensity $(100 \%)$ at $2 \theta=11.3158$ indicated that the basal spacing was $7.81972[\AA]$ and the crystallite size was $37.9 \mathrm{~nm}$. Regarding the XRD patterns of avicin A-LDH nanocomposites (Fig. $7 \mathrm{~b}, \mathrm{~d}$ and $\mathrm{f}$ ), there was a 


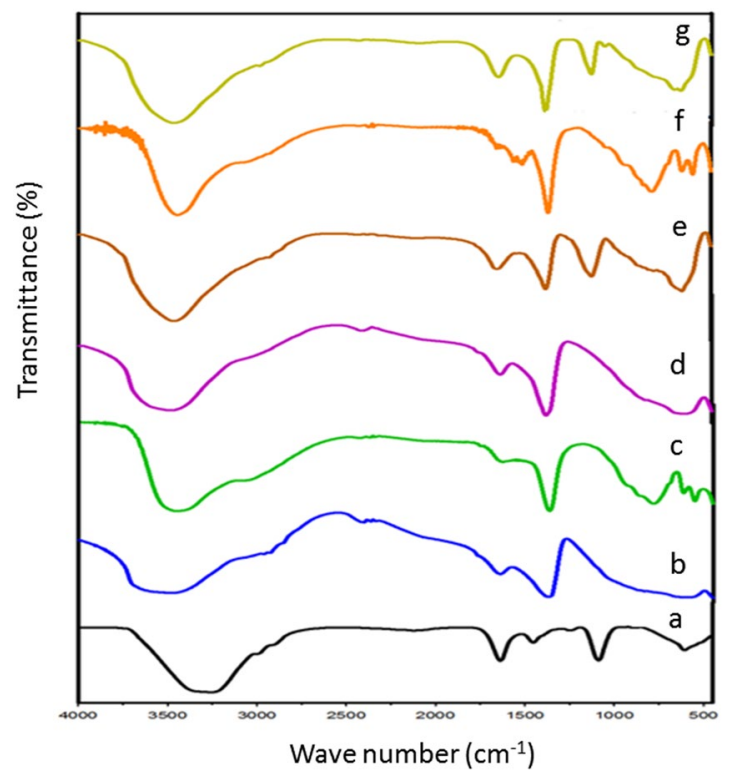

Figure 6. FT-IR spectra of (a) avicin A, (b) $\mathrm{MgAl}-\mathrm{CO}_{3} \mathrm{LDH}$, (c) $\mathrm{ZnAl}-\mathrm{CO}_{3} \mathrm{LDH}$, (d) $\mathrm{MgAl}-\mathrm{NO}_{3} \mathrm{LDH}$, (e) avicin $\mathrm{A}-\mathrm{MgAl}-\mathrm{CO}_{3} \mathrm{LDH}$ nanocomposite, (f) avicin $\mathrm{A}-\mathrm{ZnAl}-\mathrm{CO}_{3} \mathrm{LDH}$ nanocomposite, and (g) avicin A-MgAl- $\mathrm{NO}_{3} \mathrm{LDH}$ nanocomposite.

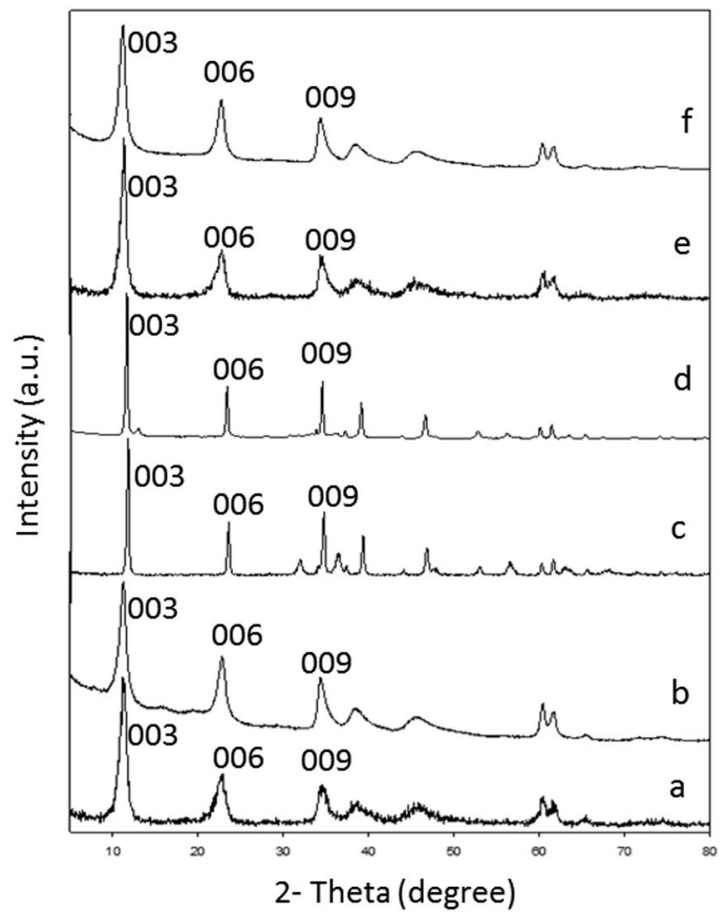

Figure 7. $\mathrm{XRD}$ patterns of (a) $\mathrm{MgAl}-\mathrm{CO}_{3} \mathrm{LDH}$, (b) avicin A-MgAl- $\mathrm{CO}_{3} \mathrm{LDH}$ nanocomposite, (c) $\mathrm{ZnAl}-\mathrm{CO}_{3}$ $\mathrm{LDH},(\mathbf{d})$ avicin A-ZnAl-CO $3 \mathrm{LDH}$ nanocomposite, (e) $\mathrm{MgAl}-\mathrm{NO}_{3} \mathrm{LDH}$, and (f) avicin A-MgAl- $\mathrm{NO}_{3} \mathrm{LDH}$ nanocomposite.

similarity between these samples and the free LDHs in the d-space and position of all peaks with a slight decrease in intensity of peaks.

The morphology of LDHs was also examined using TEM, which revealed thin nanosheets arranged in layers and stacked upon each other with a particle size of $50 \mathrm{~nm}$ for $\mathrm{MgAl}-\mathrm{CO}_{3} \mathrm{LDH}$ and $\mathrm{MgAl}-\mathrm{NO}_{3} \mathrm{LDH}$ (Fig. 8a and c), while it was $100 \mathrm{~nm}$ for $\mathrm{ZnAl}-\mathrm{CO}_{3} \mathrm{LDH}$ (Fig. 8b). 

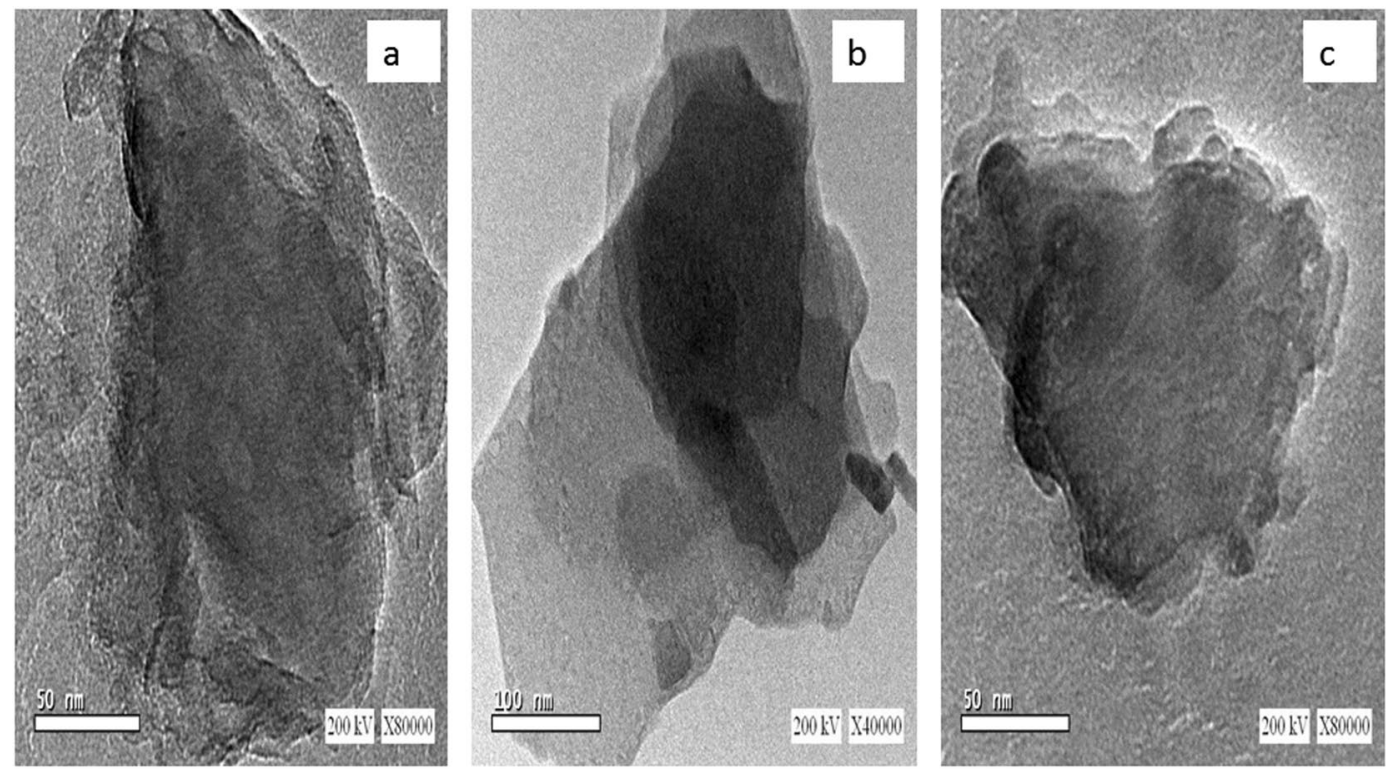

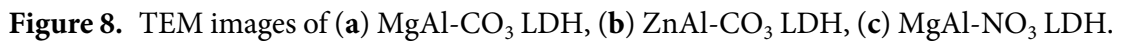

\begin{tabular}{|l|l|l|l|l|}
\hline Purification step & $\begin{array}{l}\text { Volume } \\
(\mathbf{m l})\end{array}$ & Recovery $(\mathbf{\%})$ & $\begin{array}{l}\text { Protein concentration } \\
(\mathbf{m g} / \mathbf{m l})\end{array}$ & $\begin{array}{l}\text { AMA } \\
(\mathbf{B U} / \mathbf{m l})\end{array}$ \\
\hline Culture supernatant & 250 & 100 & 17 & 1280 \\
\hline $\begin{array}{l}\text { Ammonium sulphate } \\
\text { precipitate }\end{array}$ & 10 & 128 & 249 & 40960 \\
\hline
\end{tabular}

Table 5. Steps of avicin A purification. *The protein concentration was determined using the Total Protein Kit (Greiner Diagnostic GmbH).

\section{The Antibacterial Activity of Avicin A-LDH Nanocomposites}

The stability and spectrum of AMA of the avicin A-LDH nanocomposites were compared with those obtained from the free avicin A and the different LDH precursors. In these assays, a free avicin A sample with a concentration of $249 \mathrm{mg} / \mathrm{ml}$ and AMA of $40960 \mathrm{BU} / \mathrm{ml}$ (Table 5) was used to form the various avicin A-LDH nanocomposites, which all showed an entrapment efficiency of over $50 \%$. To evaluate the bacteriocin stability, the AMA of the previously mentioned preparations were tested against Lactobacillus sakei LMGT 2313 at $72 \mathrm{~h}$ intervals for up to 24 days (Fig. 9).

Among all the nanocomposites obtained in this study, only the $\mathrm{ZnAl}-\mathrm{CO}_{3} \mathrm{LDH}$ showed a synergistic effect with avicin A when stored at RT (Fig. 9b). Even when the avicin A-ZnAl- $\mathrm{CO}_{3} \mathrm{LDH}$ nanocomposite was stored at RT for 24 days, it retained about $6.14 \%$ of its initial AMA (320 out of $5120 \mathrm{BU} / \mathrm{ml}$ ); whereas the activity of the free avicin A that has been stored at RT and at $4{ }^{\circ} \mathrm{C}$ declined nearly to baseline levels after 6 and 15 days of incubation, respectively, (Fig. 9b). On the other hand, both $\mathrm{MgAl}-\mathrm{CO}_{3}$ and $\mathrm{MgAl}-\mathrm{NO}_{3} \mathrm{LDHs}$ did not reveal any synergistic effect with the free avicin A, and the AMA of the latter was even abolished after nanocomposite formation with both LDH precursors (Fig. 9a and c).

Furthermore, the AMA of all these nanocomposite preparations was tested against a group of Gram-negative and -positive bacteria that are normally resistant to the free Avicin A, including E. coli, MRSA, and MSSA. Unfortunately, the avicin A-LDH nanocomposites did not show any remarkable AMA against the bacterial strains investigated, suggesting that the conjugation approach presented here serves mainly as a means of stably maintaining the activity of this bioactive molecule for an extended period of time.

Avicin A is a subclass IIa bacteriocin produced by E. avium HF86 that exhibits a potent AMA against many species of Gram-positive bacteria, including the food-borne pathogen L. monocytogenes ${ }^{17}$. It is well accepted that bacteriocin production can be considerably affected by media composition and growth conditions ${ }^{18,19}$. In this study, we investigated the effect of different carbon sources, nitrogen sources, $\mathrm{pH}$, incubation time, and incubation temperature on the production of avicin A.

In our preliminary screening, almost all the tested factors had an impact on the AMA of avicin A, but with varying magnitude. Regarding carbon and nitrogen sources, a study conducted by Todorov et al. ${ }^{20}$ has reported the effect of different concentrations of carbon and nitrogen sources on the production of plantaricin ST31 from Lactobacillus plantarum ST31, in which lactose, sucrose, glucose, beef extract, and yeast extract have been shown to be the most influential factors affecting the activity of the bacteriocin produced. These results agree in part with the data obtained in our study, where mannitol, lactose, peptone, and protease peptone were the most effective carbon and nitrogen sources. In agreement with its documented influence on bacteriocins production ${ }^{21}, \mathrm{pH}$ values above 6 demonstrated a considerable effect on the AMA of avicin A. This finding is interesting and needs 

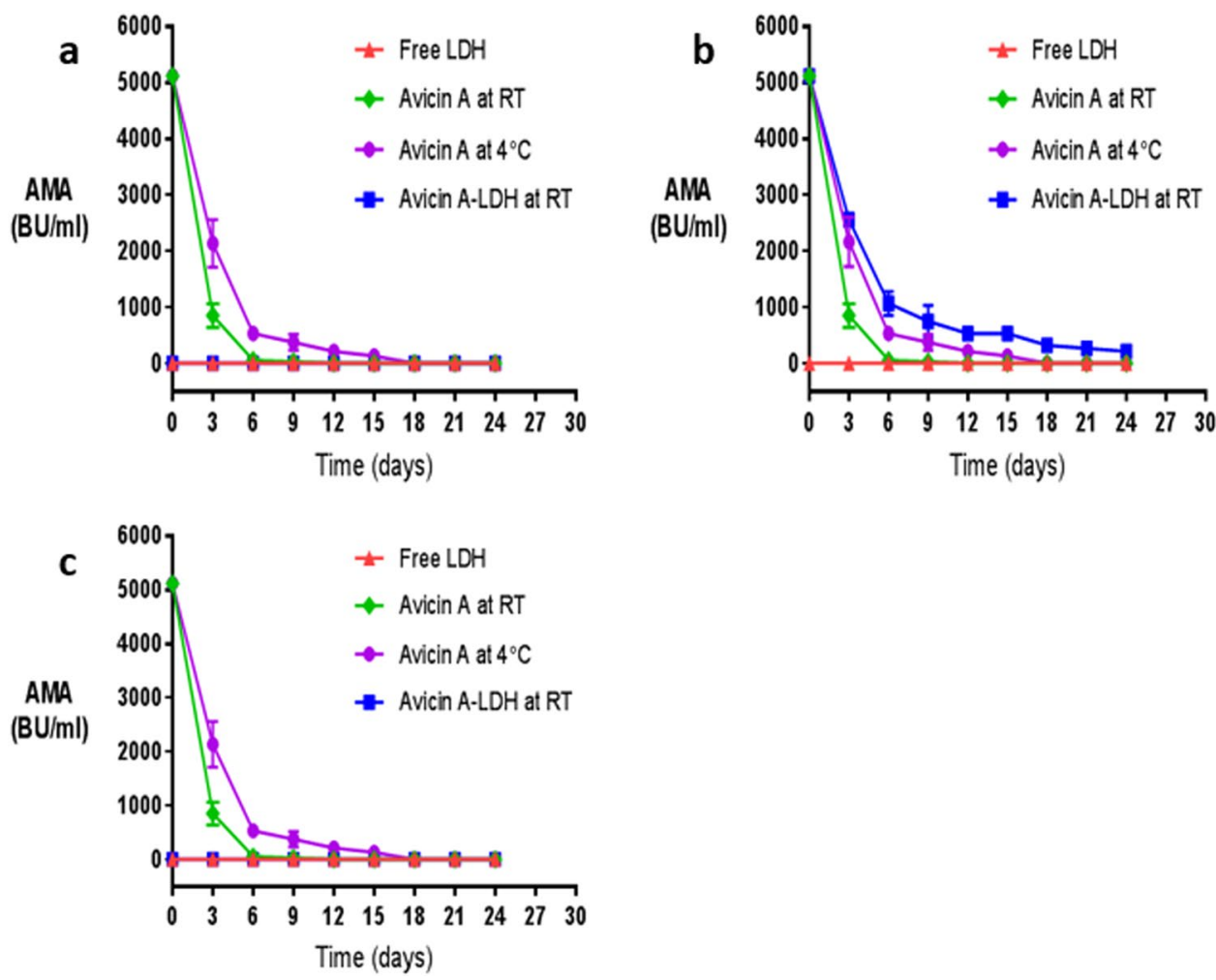

Figure 9. The AMA of the nancocomposites of (a) avicin A-MgAl- $\mathrm{CO}_{3} \mathrm{LDH},(\mathbf{b})$ avicin $\mathrm{A}-\mathrm{ZnAl}-\mathrm{CO}_{3} \mathrm{LDH}$, and (c) avicin A-MgAl- $\mathrm{NO}_{3} \mathrm{LDH}$ against L. sakei LMGT 2313 as a function of storage time. The AMA (expressed as $\mathrm{BU} / \mathrm{ml}$ ) was monitored as a function of storage time for up to 24 days. Each point represents the mean and standard error of triplicate determinations. In each graph, the AMA of the resulting avicin A-LDH nanocomposites $(\boldsymbol{\square})$ is shown in comparison with the activity of the free LDHs $(\boldsymbol{\Lambda})$, the RT-stored avicin A $(\bullet)$, and the $4{ }^{\circ} \mathrm{C}$-stored avicin $\mathrm{A}(\mathbf{O})$. In graphs a and c, please note that the line representing the AMA of the free $\mathrm{LDH}$ is superimposed on that of the resulting avicin A-LDH nanocomposites.

further investigation, because it contradicts with the posttranslation processing of prepediocin to the active bacteriocin, pediocin $\mathrm{AcH}$, which has been previously shown to occur at a $\mathrm{pH}$ below $5^{22}$. We can speculate that this processing may be confined to pediocin $\mathrm{AcH}$ only, and does not extend to include avicin $\mathrm{A}$. In our hands, the activity of avicin A increased gradually with increasing the incubation time and reached the highest level at $30 \mathrm{~h}$, which may be attributed to the accumulation of bacteriocin during the exponential phase ${ }^{23,24}$. Similar pattern has been reported for the bacteriocin produced from Lactobacillus murinus AU06, which showed the highest activity in the period between $18 \mathrm{~h}$ and $35 \mathrm{~h}^{10}$. In accordance with previous studies ${ }^{25,26}$, the optimal production of avicin $\mathrm{A}$ occured at $30^{\circ} \mathrm{C}$. However, several other reports have highlighted that the optimum production of bacteriocin can be obtained at different incubation temperatures ${ }^{21,27}$, which was not the case in avicin A. This discrepancy could be attributed to the variations among lactic acid bacteria regarding the ideal incubation temperature required for production of bacteriocins.

In our study, the fractional factorial experimental design was chosen not only to limit the number of runs required, but also to identify factor-factor interactions. The first step to increase the yield is to identify the factors that are of a significant influence on the desired response. The obtained results showed that nitrogen source, incubation temperature, $\mathrm{pH}$, and incubation time strongly affect avicin A production. Based on the interaction terms obtained from the FFD experiments, the maximum avicin A production was achieved in presence of mannitol and peptone at $30^{\circ} \mathrm{C}$, with $\mathrm{pH}$ adjustment at 7 , and incubation time $30 \mathrm{~h}$. Our findings are generally in agreement with previous investigations, which have demonstrated the strong influence of media composition, $\mathrm{pH}$, incubation time, and incubation temperature on the production of bacteriocins ${ }^{28,29}$.

Direct application of bacteriocins in food as biopreservative is faced by some challenges that limit the efficiency of these molecules, including the loss of their AMA due to proteolytic degradation and/or unfavorable interactions with other food components ${ }^{4}$. Herein, different LDHs were used to form nanocomposites with avicin $\mathrm{A}$, in an attempt to improve the stability and activity of the latter. To the best of our knowledge, this is one of the very few studies to investigate the impacts of LDHs on the AMA of bacteriocins. Characterization of LDHs, avicin A, and avicin A-LDH nanocomposites by XRD and FT-IR revealed the successful preparation of these nanocomposites. When the free LDHs and the avicin A-LDH nanocomposites were subjected to XRD analysis, they all showed the same peaks and almost the same d-space, indicating that avicin A was not intercalated into the interlayers of the LDHs. Also, unfavourable electrostatic interactions between the positively charged avicin A and the net positive charge at the surface of $\mathrm{LDH}^{30-32}$ could also eliminate the possibility of having adsorption or entrappment as the main mechanism behind this interaction. Therfore, we can assume that the avicin A-LDH 
nanocomposites produced in this study have been made through functional group conjugation rather than simple complexation. The successful formation of the avicin A-LDH nanocomposites was further confirmed by FT-IR spectra, where all peaks corresponding to the functional groups of LDHs and avicin A were clearly observed. The overlapping and shifting that happened in the FT-IR of avicin A-ZnAl- $\mathrm{CO}_{3} \mathrm{LDH}$ nanocomposite could be attributed to the strong conjugation effect between functional groups in the bacteriocin and the $\mathrm{ZnAl}-\mathrm{CO}_{3} \mathrm{LDH}^{33}$. These results are in accordance with those obtained regarding the intercalation of isoniazid into $\mathrm{MgAl} \mathrm{LDH}$, where some peaks of the isoniazid have been shown to be overlapped with peaks of LDH and shifted ${ }^{33}$.

To investigate the effect of prolonged storage on the various avicin A-LDH nanocomposites, their antimicrobial activities were tested against $L$. sakei LMGT 2313 for up to 24 days. Surprisingly, the avicin A-ZnAl- $\mathrm{CO}_{3}$ $\mathrm{LDH}$ nanocomposite possessed markedly improved stability and activity compared to the RT-stored and the $4{ }^{\circ} \mathrm{C}$-stored avicin A. This preliminary result seem more promising than those obtained by other nanodelivery systems, such as nanoliposomal encapsulation, which in certain cases, as with the AMA of the bacteriocin P34 when tested against L. monocytogenes ATCC $7644^{34}$, have resulted in a decrease of the biological activity.

Regarding the possible mode of action of avicin $\mathrm{A}-\mathrm{ZnAl}-\mathrm{CO}_{3} \mathrm{LDH}$ nanocomposite, it seems reasonable to suggest that it is a result of two steps, the first of which is the immobilization of the negatively charged bacteria by adsorption to the $\mathrm{LDH}$; while the second step is attributed to the bactericidal effect of avicin A. This is in agreement with a study conducted by Yang and his colleagues ${ }^{16}$, in which lysozyme-LDH has been shown to exhibit much higher antibacterial activity against $S$. aureus than the free lysozyme. On the other hand, avicin $\mathrm{A}-\mathrm{MgAl}-\mathrm{CO}_{3}$ and avicin $\mathrm{A}-\mathrm{MgAl}-\mathrm{NO}_{3} \mathrm{LDH}$ nanocomposites failed to demonstrate remarkable AMA against the indicator strain. Although it may be claimed that avicin A could not be released from $\mathrm{MgAl}-\mathrm{CO}_{3}$ and $\mathrm{MgAl}-\mathrm{NO}_{3}$ LDHs to provide its AMA, but further research is required to uncover the exact mechanism of this failure.

In conclusion, the present study revealed the influential impact of nitrogen sources, incubation temperature, $\mathrm{pH}$, and incubation time on avicin A production. In our hands, the maximum yield of avicin A $(2560 \mathrm{BU} / \mathrm{ml})$ was achievable following $30 \mathrm{~h}$ incubation at $30^{\circ} \mathrm{C}$ in a medium containing mannitol and peptone and adjusted to initial $\mathrm{pH}$ 7. The avicin $\mathrm{A}-\mathrm{ZnAl}-\mathrm{CO}_{3} \mathrm{LDH}$ nanocomposite demonstrated a remarkable AMA lasting for at least 24 days, whereas the activity of the free avicin A lasted only for 6 and 15 days, following storage at RT and at $4{ }^{\circ} \mathrm{C}$, respectively. In this sense, it is suggested that the approach used in this study may have a true potential for improving the applicability of bacteriocins in the food and biomedical industries. Further studies are under consideration to examine this possibility, as well as to gain a better understanding of the properties and the exact formation mechanism of the nanocomposite used in this work.

\section{Chemicals and Bacterial Strains}

All chemicals, salts, as well as carbon and nitrogen sources, were obtained from Difco Laboratories (Detroit, USA). E. avium HF86, the producer strain of avicin A, was kindly provided by one of the authors (A. O. El-Gendy), and its purity was checked on bile esculin agar (Laboratory Conda, Spain). The identity of this bacteriocinogenic strain was confirmed by sequencing of its $16 \mathrm{~S}$ rRNA gene, followed by BLAST homology search at the NCBI database. The in vitro susceptibility of this isolate against different antibiotics was also investigated. Unless otherwise noted, cultures of this strain were propagated in Man Rogosa Sharpe (MRS) broth (Oxoid, England) at $30^{\circ} \mathrm{C}$. The stock cultures of all bacterial strains used in this study, including the sensitive indicator strain Lactobacillus sakei LMGT 2313 , were kept frozen at $-80^{\circ} \mathrm{C}$ in MRS/glycerol broth $(60: 40 \mathrm{v} / \mathrm{v})$ until analysed.

\section{Production and Partial Purification of Avicin A}

An overnight culture of E. avium HF86 was inoculated at $1 \%$ into $100 \mathrm{ml}$ MRS broth and incubated at $30^{\circ} \mathrm{C}$ for $18 \mathrm{~h}$ in a static condition. The bacterial cells were removed by centrifugation at $10,000 \mathrm{rpm}$ for $20 \mathrm{~min}$, at $4^{\circ} \mathrm{C}$. The cell-free supernatant was adjusted to $\mathrm{pH} 6.5$ by the addition of $1 \mathrm{~N} \mathrm{NaOH}$ and used as a crude bacteriocin preparation to study the effect of growth conditions and media composition on bacteriocin production.

To form nanocomposites with LDH, $500 \mathrm{ml}$ of MRS broth were inoculated with $1 \%$ (v/v) of an overnight culture of the producer strain. The bacteriocin was partially purified from the cell-free supernatant by precipitation with $50 \%(\mathrm{w} / \mathrm{v})$ ammonium sulfate, followed by centrifugation at $10,000 \mathrm{rpm}$ for $30 \mathrm{~min}$, at $4{ }^{\circ} \mathrm{C}$. The precipitated protein was dissolved in $10 \mathrm{ml}$ distilled water, and therefore, the finally obtained protein was 50x concentrated. The total amount of protein was determined using the Total Protein Kit (Greiner Diagnostic GmbH), and the concentrated bacteriocin was used for conjugation with LDH nanoparticles.

\section{Investigation of the Activity and Identity of Avicin A}

The antimicrobial activity (AMA) of avicin A was evaluated by the agar well-diffusion method, using the previously mentioned indicator strain. In addition to determination of inhibition zone diameter, bacteriocin samples were serially diluted two-fold, and the reciprocal of the highest inhibitory dilution was used to express the arbitrary activity units (AU) per millilitre. To verify the protein nature of avicin A, the culture supernatant was treated with $1 \mathrm{mg} / \mathrm{ml}$ of proteinase $\mathrm{K} \mathrm{enzyme} \mathrm{(Sigma)} \mathrm{for} 60 \mathrm{~min}$ at $37^{\circ} \mathrm{C}$. The expression of the gene encoding the avicin A was also confirmed by subjecting the bacterial mRNA to reverse transcription PCR (RT-PCR), then the resulting cDNA was PCR amplified using specific primers (Table 1), and the amplified products were visualized by electrophoresis in $2 \%$ agarose gel stained with ethidium bromide to verify band size.

\section{Effect of Media Composition and Growth Conditions on Avicin A Production}

Screening of the effects of media composition and growth conditions on avicin A production were conducted using $100 \mathrm{ml}$ of MRS broth inoculated with $1 \%(\mathrm{v} / \mathrm{v})$ of an overnight culture of E. avium HF86 and subjected to different parameters, such as carbon and nitrogen source supplementation (Table 2), various pH values $(4,5,6,7$ and 8 ), incubation time $(6,12,18,24$, and $30 \mathrm{~h})$, and incubation temperatures $\left(20,25,30,37\right.$, and $\left.40^{\circ} \mathrm{C}\right)$ (Table 3$)$. 
Following incubation, samples of the produced bacteriocin were collected to examine the AMA by determination of inhibition zone diameter.

The Fractional Factorial Experimental Design (FFD)

Based on the preliminary screening of media composition and growth conditions carried out by one-variable-at-a-time (OVAT) approach, the most important five factors were examined, with two levels each, for their combined effect on avicin A production (Table 4). FFD $\left(2^{\mathrm{k}-1}\right)$ was used to run 16 independent experiments ${ }^{13}$. For five factors, the model's equation is:

$$
\begin{aligned}
\mathrm{Y}= & b_{0}+b_{1} x_{1}+b_{2} x_{2}+b_{3} x_{3}+b_{4} x_{4}+b_{5} x_{5}+b_{12} x_{1} x_{2}+b_{13} x_{1} x_{3}+b_{14} x_{1} x_{4}+b_{15} x_{1} x_{5} \\
& +b_{23} x_{2} x_{5}+b_{24} x_{1} x_{5}+b_{25} x_{1} x_{5}+b_{34} x_{1} x_{5}+b_{35} x_{1} x_{5}+b_{45} x_{1} x_{5}
\end{aligned}
$$

where, $\mathrm{Y}$ is the predicted response (bacteriocin activity in terms of $\mathrm{BU} / \mathrm{ml}$ ); $b_{0}$ the intercept; $b_{1}, b_{2}, b_{3}, b_{4}$, and $b_{5}$ are the linear coefficients which express the direct effect of factors on response; $b_{12}, b_{13}, b_{14}, b_{15}, b_{23}, b_{24}, b_{25}, b_{34}$, $b_{35}$, and $b_{45}$ are interaction coefficients reflecting trends and magnitude of interaction among the represented factors; $x_{1}$ is the carbon source; $x_{2}$ is the nitrogen source; $x_{3}$ is the initial $\mathrm{pH} ; x_{4}$ is the incubation time; and $x_{5}$ is the incubation temperature.

\section{Preparation of LDH Nanoparticles}

$\mathrm{MgAl}-\mathrm{CO}_{3}, \mathrm{ZnAl}-\mathrm{CO}_{3}$, and $\mathrm{MgAl}-\mathrm{NO}_{3} \mathrm{LDHs}$ were synthesized by the co-precipitation method previously described by Mohanambe and colleague ${ }^{35}$, and the molar ratio of divalent cations to trivalent cations $\left(\mathrm{M}^{2+}: \mathrm{M}^{3+}\right)$ was kept at 3:1 in all cases. Briefly, an aqueous solution containing $\mathrm{NaOH}(0.5 \mathrm{M})$ was added drop wise into a solution containing the specific amounts of the divalent and trivalent cations, the final $\mathrm{pH}$ of the solution was maintained between 8 and 10, and the resulting slurry was aged at $65^{\circ} \mathrm{C}$ for $18 \mathrm{~h}$ while stirring. For preparing $\mathrm{MgAl}-\mathrm{NO}_{3} \mathrm{LDH}$, the experiment was done carefully under atmospheric nitrogen. Finally, the resulting precipitate was washed several times with hot deionized water and allowed to dry overnight at $60^{\circ} \mathrm{C}$.

\section{Formation of Avicin A-LDH Nanocomposites}

Nanocomposites were prepared by adding the partially purified avicin A to the LDH nanoparticles in a molar ratio of $2: 1$, and the mixture was allowed to age at $\leq 4^{\circ} \mathrm{C}$ for $72 \mathrm{~h}$, with vigorous stirring under nitrogen. The slurry was subjected to centrifugation $(3,400 \mathrm{rpm})$ for $15 \mathrm{~min}$ at $4{ }^{\circ} \mathrm{C}$. The resulting precipitate was washed thrice with deionized water, centrifuged at $3,400 \mathrm{rpm}$, and dried at room temperature (RT). The concentration and the antimicrobial activity of the residual non-conjugated avicin A, present in the supernatant fraction obtained after the first centrifugation step, were measured to determine the entrapment efficiency.

Physicochemical Characterizations of LDHs, Avicin A, and Avicin A-LDH Nanocomposites. In this study, avicin A was characterized by Fourier transform infrared (FT-IR) spectroscopy, while the LDH nanoparticles and avicin A-LDH nanocomposites were characterized by X-ray diffraction (XRD) and FT-IR spectroscopy. XRD patterns were recorded by PANalytical Empyrean Diffractometer system using $\mathrm{Cu}(\mathrm{K} \alpha)$ radiation $(\lambda=1.54 \AA)$ at $40 \mathrm{kV}$ and $30 \mathrm{~mA}$, with $2 \theta$ angles ranging from $5^{\circ}$ to $79.9^{\circ}$. FT-IR spectra were recorded using a Vertex-70 spectrophotometer (Bruker, Germany) in the $4000-400 \mathrm{~cm}^{-1}$ range using the $\mathrm{KBr}$ pellet technique. To study the morphology of LDH nanoparticles, the synthesized LDHs were examined using Transmission Electron microscope (TEM) (JEOL-JEM 2100, Japan) with an acceleration voltage of $200 \mathrm{KV}$.

\section{Stability and Spectrum of Activity of the Avicin A-LDH Nanocomposites in Comparison with the Free Materials}

To evaluate the stability of their antimicrobial activity after prolonged storage, the AMA of RT-stored avicin $\mathrm{A}, 4^{\circ} \mathrm{C}$-stored avicin $\mathrm{A}$, the three nanocomposites (avicin A-MgAl-CO3 LDH, avicin A-ZnAl-CO3 LDH, and avicin A-MgAl-NO3 LDH), and the free LDH nanoparticles, all stored at RT, were tested against Lactobacillus sakei LMGT 2313 at $72 \mathrm{~h}$ intervals for up to 24 days. Furthermore, the AMA of all these preparations was tested against bacterial strains that are normally resistant to the free Avicin A, including Escherichia coli ATCC 25922, methicillin-resistant Staphylococcus aureus (MRSA; ATCC 43300), and methicillin-sensitive Staphylococcus aureus (MSSA; ATTC 25923).

\section{Statistical Analysis}

All experiments were carried out in triplicate and in a randomized order. Results were analysed by statistical software (Matlab; version 7.1.0.246 (R14); Math Works, Inc., Natick, MA) to calculate the coefficients, and hence, evaluate the effects of linear and interaction terms of independent variables.

\section{References}

1. Tagg, J. R., Dajani, A. S. \& Wannamaker, L. W. Bacteriocins of gram-positive bacteria. Bacteriological reviews 40, 722-756 (1976).

2. Cotter, P. D., Hill, C. \& Ross, R. P. Bacteriocins: developing innate immunity for food. Nature Reviews Microbiology 3, 777-788 (2005).

3. El-Gendy, A. O., Essam, T. M., Amin, M. A., Ahmed, S. H. \& Nes, I. F. Clinical Screening for Bacteriocinogenic Enterococcus faecalis Isolated from Intensive Care Unit Inpatient in Egypt. Journal of Microbial \& Biochemical Technology 4, 161-167 (2013).

4. Fahim, H. A., Khairalla, A. S. \& El-Gendy, A. O. Nanotechnology: a valuable strategy to improve bacteriocin formulations. Frontiers in Microbiology 7, 1385, doi:10.3389/fmicb.2016.01385 (2016).

5. Bradshaw, J. P. Cationic antimicrobial peptides. BioDrugs 17, 233-240 (2003).

6. Parente, E. \& Ricciardi, A. Production, recovery and purification of bacteriocins from lactic acid bacteria. Applied Microbiology and Biotechnology 52, 628-638 (1999).

7. Carolissen-Mackay, V., Arendse, G. \& Hastings, J. W. Purification of bacteriocins of lactic acid bacteria: problems and pointers. International Journal of Food Microbiology 34, 1-16 (1997). 
8. Jung, D.-S., Bodyfelt, F. W. \& Daeschel, M. A. Influence of fat and emulsifiers on the efficacy of nisin in inhibiting Listeria monocytogenes in fluid milk. Journal of Dairy Science 75, 387-393 (1992).

9. Zacharof, M. P. \& Lovitt, R. W. Low molecular weight liquid media development for Lactobacilli producing bacteriocins. Journal of Chemical Technology and Biotechnology 88, 72-80 (2013).

10. Elayaraja, S., Annamalai, N., Mayavu, P. \& Balasubramanian, T. Production, purification and characterization of bacteriocin from Lactobacillus murinus AU06 and its broad antibacterial spectrum. Asian Pacific journal of tropical biomedicine 4, S305-S311 (2014).

11. Suganthi, V. \& Mohanasrinivasan, V. Optimization studies for enhanced bacteriocin production by Pediococcus pentosaceus KC692718 using response surface methodology. Journal of food science and technology 52, 3773-3783 (2015).

12. Oh, S., Rheem, S., Sim, J., Kim, S. \& Baek, Y. Optimizing conditions for the growth of Lactobacillus casei YIT 9018 in tryptone-yeast extract-glucose medium by using response surface methodology. Applied and environmental microbiology 61, 3809-3814 (1995).

13. Gunst, R. F. \& Mason, R. L. Fractional factorial design. Wiley Interdisciplinary Reviews: Computational Statistics 1, 234-244, doi:10.1002/wics.27 (2009).

14. Ladewig, K., Xu, Z. P. \& Lu, G. Q. Layered double hydroxide nanoparticles in gene and drug delivery. Expert Opinion on Drug Delivery 6, 907-922 (2009).

15. Xia, S.-J., Ni, Z.-M., Xu, Q., Hu, B.-X. \& Hu, J. Layered double hydroxides as supports for intercalation and sustained release of antihypertensive drugs. Journal of Solid State Chemistry 181, 2610-2619 (2008).

16. Yang, Q.-Z., Chang, Y.-Y. \& Zhao, H.-Z. Preparation and antibacterial activity of lysozyme and layered double hydroxide nanocomposites. Water research 47, 6712-6718 (2013).

17. Birri, D. J., Brede, D. A., Forberg, T., Holo, H. \& Nes, I. F. Molecular and genetic characterization of a novel bacteriocin locus in Enterococcus avium isolates from infants. Applied and environmental microbiology 76, 483-492 (2010).

18. Turgis, M., Vu, K. D., Millette, M., Dupont, C. \& Lacroix, M. Influence of environmental factors on bacteriocin production by human isolates of Lactococcus lactis MM19 and Pediococcus acidilactici MM33. Probiotics and antimicrobial proteins 8, 53-59 (2016).

19. Mohamed, W. F., Khalil, K. M., Shady, H. M. A. \& Sayed, H. A. E. Activity range determination and optimization of various environmental conditions FOR BACTERIOCIN production by lactobacillus acidophilus and lactobacillus plantarum. The Egyptian Journal of Experimental Biology (Botany) 12, 53-66 (2016).

20. Todorov, S., Gotcheva, B., Dousset, X., Onno, B. \& Ivanova, I. Influence of growth medium on bacteriocin production in Lactobacillus plantarum ST31. Biotechnology \& Biotechnological Equipment 14, 50-55 (2000).

21. Kim, M.-H., Kong, Y.-J., Baek, H. \& Hyun, H.-H. Optimization of culture conditions and medium composition for the production of micrococcin GO5 by Micrococcus sp. GO5. Journal of biotechnology 121, 54-61 (2006).

22. Yang, R. \& Ray, B. Factors influencing production of bacteriocins by lactic acid bacteria. Food Microbiology 11, 281-291 (1994).

23. Delgado, A., Brito, D., Peres, C., Noe-Arroyo, F. \& Garrido-Fernández, A. Bacteriocin production by Lactobacillus pentosus B96 can be expressed as a function of temperature and $\mathrm{NaCl}$ concentration. Food Microbiology 22, 521-528 (2005).

24. Mataragas, M., Metaxopoulos, J., Galiotou, M. \& Drosinos, E. Influence of $\mathrm{pH}$ and temperature on growth and bacteriocin production by Leuconostoc mesenteroides L124 and Lactobacillus curvatus L442. Meat Science 64, 265-271 (2003).

25. Cheigh, C.-I. et al. Influence of growth conditions on the production of a nisin-like bacteriocin by Lactococcus lactis subsp. lactis A164 isolated from kimchi. Journal of Biotechnology 95, 225-235 (2002).

26. Matsusaki, H., Endo, N., Sonomoto, K. \& Ishizaki, A. Lantibiotic nisin Z fermentative production by Lactococcus lactis IO-1: relationship between production of the lantibiotic and lactate and cell growth. Applied Microbiology and Biotechnology 45, 36-40 (1996).

27. Krier, F., Revol-Junelles, A. \& Germain, P. Influence of temperature and $\mathrm{pH}$ on production of two bacteriocins by Leuconostoc mesenteroides subsp. mesenteroides FR52 during batch fermentation. Applied microbiology and biotechnology 50, 359-363 (1998).

28. Pal, A., Ramana, K. \& Bawa, A. Simplification and optimization of deMan Rogosa Sharpe (MRS) medium for enhanced production of bacteriocin by Weissella paramesenteroides DFR-8. Journal of food science and technology 47, 258-265 (2010).

29. Hwanhlem, N., Chobert, J.-M. \& Aran, H. Bacteriocin-producing lactic acid bacteria isolated from mangrove forests in southern Thailand as potential bio-control agents in food: isolation, screening and optimization. Food Control 41, 202-211 (2014).

30. Sels, B. et al. Layered double hydroxides exchanged with tungstate as biomimetic catalysts for mild oxidative bromination. Nature 400, 855-857 (1999).

31. Vadyvaloo, V. et al. Cell-surface alterations in class IIa bacteriocin-resistant Listeria monocytogenes strains. Microbiology 150, 3025-3033 (2004).

32. Elgiddawy, N., Essam, T. M., El Rouby, W. M., Raslan, M. \& Farghali, A. A. New approach for enhancing Chlorella vulgaris biomass recovery using ZnAl-layered double hydroxide nanosheets. Journal of Applied Phycology, 1399-1407, doi:10.1007/s10811-017-10505 (2017).

33. Saifullah, B. et al. Development of a biocompatible nanodelivery system for tuberculosis drugs based on isoniazid-Mg/Al layered double hydroxide. International journal of nanomedicine 9, 4749-4762 (2014).

34. da Silva Malheiros, P., Sant'Anna, V., Micheletto, Y. M. S., da Silveira, N. P. \& Brandelli, A. Nanovesicle encapsulation of antimicrobial peptide P34: physicochemical characterization and mode of action on Listeria monocytogenes. Journal of Nanoparticle Research 13, 3545-3552 (2011).

35. Mohanambe, L. \& Vasudevan, S. Anionic clays containing anti-inflammatory drug molecules: Comparison of molecular dynamics simulation and measurements. The Journal of Physical Chemistry B 109, 15651-15658 (2005).

36. Kjos, M., Nes, I. F. \& Diep, D. B. Mechanisms of resistance to bacteriocins targeting the mannose phosphotransferase system. Applied and environmental microbiology 77, 3335-3342 (2011).

37. Ahmad, M. S. et al. Exploring the Antimicrobial and Antitumor Potentials of Streptomyces sp. AGM12-1 Isolated from Egyptian Soil. Frontiers in Microbiology 8, doi:10.3389/fmicb.2017.00438 (2017).

38. Birri, D. J., Brede, D. A., Tessema, G. T. \& Nes, I. F. Bacteriocin production, antibiotic susceptibility and prevalence of haemolytic and gelatinase activity in faecal lactic acid bacteria isolated from healthy Ethiopian infants. Microbial ecology 65, 504-516 (2013).

\section{Acknowledgements}

This work was partially funded by Beni-Suef University annual research grants, 2014.

\section{Author Contributions}

A.E., A.K., W.E., and A.F. designed the research. H.F. carried out the experiments, analysed the data, and interpreted the results. A.E. and A.K. participated in the microbiological and molecular biology experiment. W.E. and A.F. participated in the nanotechnological part of the study. I.N. contributed in the design and analysis of the fractional factorial experiment. H.F. drafted the manuscript and all authors revised and approved the final manuscript. 


\section{Additional Information}

Supplementary information accompanies this paper at doi:10.1038/s41598-017-10157-9

Competing Interests: The authors declare that they have no competing interests.

Accession codes: The sequence of the DNA encoding the 16S rRNA of the test E. avium HF86 strain was deposited in GenBank with accession number KY921715.

Publisher's note: Springer Nature remains neutral with regard to jurisdictional claims in published maps and institutional affiliations.

Open Access This article is licensed under a Creative Commons Attribution 4.0 International (c) License, which permits use, sharing, adaptation, distribution and reproduction in any medium or format, as long as you give appropriate credit to the original author(s) and the source, provide a link to the Creative Commons license, and indicate if changes were made. The images or other third party material in this article are included in the article's Creative Commons license, unless indicated otherwise in a credit line to the material. If material is not included in the article's Creative Commons license and your intended use is not permitted by statutory regulation or exceeds the permitted use, you will need to obtain permission directly from the copyright holder. To view a copy of this license, visit http://creativecommons.org/licenses/by/4.0/.

(C) The Author(s) 2017 